\title{
A CONCEPTUAL AND EMPIRICAL VALIDATION OF THE HOUSEHOLD LIFECYCLE CONCEPT IN SOUTH AFRICA
}

\author{
J VAN ROOYEN \\ P J DU PLESSIS \\ Department of Marketing and Communication Management \\ University of Pretoria
}

\begin{abstract}
The family life cycle theory was used in the research as a tool for segmenting markets and developing marketing strategy. Households are not always family based and can take the form of single households, same gender households, and cohabiter-type households, each displaying distinctly different consumption behaviours. The researchers investigated whether the household life cycle theory is a valuable basis for segmentation in the South African environment.

The results indicated that although the household life cycle theory has proven useful in differentiating between households in their consumption behaviour, it should not be used exclusively in segmenting markets due to the high level of within-stage heterogeneity.
\end{abstract}

\section{OPSOMMING}

Die gesinslewensikluskonsep is as 'n hulpmiddel gebruik in marksegmentering om bemarkingstrategieë te ontwikkel. Huishoudings is egter nie altyd gesins-gebaseerd nie en kan bestaan uit enkel-, dieselde geslag-, en saamblyhuishoudings wat elkeen merkbare verskille kan toon ten opsigte van verbruikspatrone. Ondersoek is gedoen oor die huishoudingslewensiklusteorie as basis vir marksegmentering in die Suid-Afrikaanse omgewing. Die resultate dui daarop dat ofskoon die huishoudingslewensiklus bruikbaar is om tussen huishoudings te differensieer in terme van verbruiksgedrag, diè teorie nie uitsluitlik en in isolasie gebruik moet word nie vanweë die hoë vlak van binne-stadium verskillendheid.

In the past the family life cycle theory was a useful tool for segmenting markets and developing marketing strategy. The basic premise of this theory is that most families go through a progression of stages, each with its own characteristics, financial situation and purchasing patterns (Hawkins, Best \& Coney, 2001, p.196).

It is contended that there is no longer a single dominant cycle through which families progress, but rather a variety of cycles through which different families progress (Hawkins et al., 2001, p.196).

Households are not always family based and can take the form of single households, same gender households, and cohabiter-type households, each displaying distinctly different consumption behaviours (Schaninger \& Danko, 1993, p.583). In New Zealand, for instance, family households constitute 62 percent of all households and single person households 20 percent (Neal, Quester \& Hawkins 2002, p.338). South Africa has a relatively lower percentage of single person households (11\%) and a relatively higher percentage (76\%) of family households (Statistics South Africa, 1995).

Marketers often choose life cycle groups as their target market, yet target households are not always family based (Kotler, 2000 , p.167). Because a relatively large proportion of households are non-family households, the concept of the family life cycle needs to be broadened to the concept of the household life cycle (HLC). In this paper the term household will be used in the context of people who occupy the same unit of housing, implying a more inclusive term than family. Accordingly, the term HLC will be used instead of family life cycle for the sake of consistency.

The essence of the HLC theory is its ability to identify groups of households that react similarly (or show similar consumption behaviour) to the consequences of life-changing events throughout the HLC. Gilly and Enis (1982, p.273) identify such life-changing events as marriage and divorce, death, and the

Requests for copies should be addressed to: PJ du Plessis, Department of Marketing and Communication Management, University of Pretoria

Pretoria, 0002 addition/departure of children. Household groups therefore typically undergo a cyclical process of birth, growth, decay and dissolution over time (Arnould, Price \& Zinkhan, 2002, p.511).

The authors argue that these life-changing events cause changes in household consumption needs (consequences) that in turn translate into changes in consumption behaviours (reactions)

Since the HLC model combines trends in earning power with demands placed on income, it has been described as a useful way of classifying and segmenting individuals and families with distinct needs, attitudes and desires.

Various researchers have developed different HLC models, which are more or less all based on the age and marital status of the adult members of the household and the presence and age of the children (Hawkins et al., 2001, p.196).

The general HLC models (Wells \& Gubar, 1966; Murphy \& Staples, 1979; and Gilly \& Ennis, 1982) proposed over the years can be synthesised into five basic stages (Schiffman \& Kanuk, 1997, p.361):

- Stage 1: Bachelorhood - young single adult living apart from parents

- Stage 2: Honeymooners - young married couple

- Stage 3: Parenthood - married couple with at least one child living at home (Full Nest 1, 11 and 111)

- Stage 4: Postparenthood - an older married couple with no children living at home (Empty Nest 1 and 11)

- Stage 5: Dissolution - one surviving spouse

The literature review revealed that the most significant contribution to the redefinition of the traditional family life cycle concept was that of Gilly and Enis (1982) because it provided a model most representative of modern society (Schaninger \& Danko, 1993, p.585; Redondo-Bellón, Roya-Vela \& Alidas-Manzano, 2001, p.622; and Liu \& Putler, 2001, p.11).

The Gilly and Enis (1982, p.173) family life cycle model is based on a selection of alternative life cycle paths, defining 14 HLC stages. In their redefinition of the Wells and Gubar (1966) HLC 
model, Gilly and Enis specifically aimed at designing an approach that classified all households as opposed to the alternative models available at the time that did not do so.

Gilly and Enis (1982, p.273) argue that earlier models such as the Murphy and Staples (1979) HLC model and the Wells and Gubar (1966) HLC model had an overly inflated "other" category, which might not adequately explain all consumption behaviour. In an attempt to overcome this weakness, they explicitly incorporated a number of non-traditional paths such as delayed marriage and parenthood, childless households, remarriage, middle-aged and older bachelors, never married or widowed single parents, cohabiting couples and mature nest families.

Gilly and Enis (1982, p.272) identified three major issues demanding the redefinition of the HLC:

- Childless and delayed marriages: There are more life styles than the previous (traditional) HLC model recognised. Women are delaying and even avoiding childbearing, more women are remaining single, more marriages are childless, and more couples are postponing the birth of their first child. Gilly and Enis argue that these decisions are a function of the broadening perspective of women in the sense that they are becoming more self-sufficient and no longer consider raising children as their primary role.

- Single parent households: The traditional HLC model does not recognise single parent households. When Gilly and Enis conducted their research there were more than eight million single parent households in the United States.

- Male head of household: Children have a significant effect on a family's consumption behaviour and are consequently considered a key determinant of the life cycle stage. Gilly and Enis (1982, p.272) regard the woman's age as important in defining the various stages in the family life cycle.

Gilly and Enis (1982, p.272) observed that the "traditional" family life cycle of marriage, birth of children, departure of children, and death of spouse was changing because of the growth in the number of alternative life style choices available to women at the time (early 1980s).

The academic literature reflects differences of opinion on the usefulness of the HLC model in market segmentation (Derrick \& Lehfeld, 1980, pp.214-215; Wilkes, 1995, p.40; Liu \& Putler, 2001, p.24; and Redondo-Bellón et al., 2001, p.635).

Derrick and Lehfeld (1980, pp.214-215) argue that the HLC model has limited use as a method of segmentation since a great deal of predictive information goes astray in the classification of households, resulting in heterogeneity within the various stages of the HLC. Derrick and Lehfeld (1980) further point out that the literature fails to explain what happens to households' behaviour as they move from one stage in the HLC to another given the continuously changing underlying assumptions of, for example, birth rates, marriages and family size.

Liu and Putler (2001, p.24) postulate that the HLC model has taken on the status of "received wisdom" in both teaching and practice owing to its lack of empirical value. According to these researchers, the model has a high level of face validity in that most marketers either know or can imagine people and households that fall into each life cycle stage. Based on a combination of casual empiricism and stereotypes, they predict how spending patterns will vary across these households.

The validity of the HLC model as a valuable empirical tool in the analysis of consumer spending behaviour has been confirmed by Wilkes (1995, p.40), who found that as households make the transition from one stage to the next, resources appear to undergo a reallocation to accommodate the changed circumstances and demands. Redondo-Bellón et al. (2001, p.635) supported this finding and applied the HLC model to the Spanish environment.
In the USA interest has been shown in the boomerang kids, that is adult children who have returned to their parents' homes because of financial insecurity or divorce. Forty percent of young adults have been part of this "boomerang" (Arnould et al., 2002, p.513).

The literature search revealed that the HLC model has probably never been validated in the South African environment, thus posing a challenge to the South African marketing community. Redondo-Bellon et al. (2001, p.635) point out that the sociodemographic peculiarities of different countries may well call for locally adapted HLC models.

Various socio-economic trends have caused the proliferation of full-nest type households in South Africa (Langschmidt \& Hoets, 2001, p.12). Langschmidt and Hoets point out that younger people in South Africa are tending to live in their family/parental homes for longer periods of time. Although this has always been the case with young black people, this trend is increasing among their white counterparts. Since this occurs mainly in the rural areas, the extended family structure generally means that additional income enters the household. Furthermore, when people are retrenched and unable to find work, they tend to return to their family homes thus placing renewed pressure on overall household income.

Various sociodemographic peculiarities characterise the South African market. Income in South Africa is unevenly distributed in terms of race, gender and urban/non-urban area (Hirschowitz, 1997, p.9). If it is assumed that the level of household income influences household consumption behaviour, households within each of the stages of the HLC may differ significantly with regard to their overall consumption behaviour. This is possible even though the various stages in the HLC differ widely from one another in such behaviour.

These factors may not only cause South African household compositions to be quite different from those in the United States - they may also impact on differences in consumption behaviour throughout the HLC.

There may indeed be value in the HLC model as a basis for market segmentation, but this needs to be investigated more closely in the South African environment.

Apart from the fact that the HLC model has not likely been validated in South Africa, the most recent and most quoted version of the HLC model (Gilly \& Enis, 1982) is already 20 years old. The period between the original Wells and Gubar (1966) HLC conceptualisation, and the first of the modernised HLCs, done by Murphy and Staples (1979), was as short as 13 years. The question is therefore whether the Gilly and Enis (1982) model can still accommodate non-traditional household formats since society has changed so radically since 1982 .

There is a need to investigate whether the HLC model serves as a valuable basis for segmentation in South Africa today.

\section{OBJECTIVES AND HYPOTHESES}

The first objective of this study is to establish whether the HLC model is a useful tool for understanding consumption behaviour in South African households. It will address a basic HLC question, namely whether the allocation of resources within the household - to satisfy a broad range of consumption needs - is markedly different between the various stages of the HLC.

It is acknowledged that the South African market is diverse, both in terms of population groups, levels of urbanisation and household incomes. The second objective of the study is consequently to examine whether the differences in consumption behaviour are significant with reference to the population group of the head of the household, the level of urbanisation of the household and the level of household income. 
Finally, the study will examine whether the HLC model proposed by Gilly and Enis (1982) is still effective in accommodating/covering non-traditional household formats in South Africa.

The following hypotheses are stated:

$\mathrm{H}_{1}$ : The applied household life cycle model differentiates between households with respect to their overall consumption behaviour.

$\mathrm{H}_{2}$ : There are significant differences between the households' overall consumption behaviour within the various stages of the household life cycle and the population group of the head of the household.

$\mathrm{H}_{3}$ : There are significant differences between the households' overall consumption behaviour within the various stages of the household life cycle and the level of income.

$\mathrm{H}_{4}$ : There are significant differences between the households' overall consumption behaviour within the various stages of the household cycle and the level of urbanisation

\section{METHOD}

\section{Data and sample size}

Data from the 1995 October household income and expenditure survey (IES) were used. At the time of the research (2001) the 1999 household income and expenditure survey was not available. The IES provides household income and expenditure information for a period of one year (1994-1995) for South African households on a broad range of detailed income and expenditure categories, making it possible to examine the potential effects of the HLC across a number of different expenditure categories (Statistics South Africa,1995). This source was considered appropriate in the present study because most of the other empirical studies reviewed made use of similar sources (Liu \& Putler, 2001, p.10; Redondo-Bellón et al., 2001, p.625; Wilkes, 1995, p.30; and Murphy \& Staples, 1979, p.16).

Two surveys - the Central Statistical Service annual October household survey (OHS) and the IES - were conducted concurrently during October 1995. Information for the IES was obtained, as far as possible, from the same 30000 households that were used for the 1995 OHS. All together, 3000 enumerator areas were drawn for the sample, and ten households were visited in each area. The sample was stratified by population group, province, and geographical location (urban/rural).

\section{Household life cycle stages and composition variables}

A modified version of the Gilly and Enis (1982) HLC model was used to compare household life stage income and expenditure.

Three different household composition variables are used to define household life cycle stages in the Gilly and Enis (1982) framework. These are:

- Whether there are one or two adults present in the household.

- Whether there are children present in the household.

- Whether the youngest child is younger than six, or between the ages of six and 21 years.

- Whether the household head is younger than 35 years, between the ages of 35 and 64 years (retirement age), or has reached retirement age (older than 64 years).

There are two reasons why this framework was selected over competing HLC modernisations. Firstly, the Gilly and Enis (1982) framework is considered superior in that it better captures actual household expenditure behaviour and allows for the classification of a much higher percentage of non-traditional households. Secondly, the Gilly and Enis (1982) framework has been more widely adopted in extant empirical work.

The cross-classification of the above three household composition variables leads to 18 different combinations
(2X3X3). In their cross-classification, Gilly and Enis (1982) made two modifications in defining household life cycle stages. Specifically, they omitted households with children present where the household head was 65 years of age or older (a total of four cases in the cross-classification), and they combined the two cases where there were children present in a single head household, where the head was between the ages of 35 and 64 . In other words, all households with a single household head between the ages of 35 and 64, with children present, were grouped together regardless of the age of the children. As a result of these modifications, the Gilly and Enis framework consists of 13 life cycle stages.

In the current study, the Gilly and Enis (1982) framework has been modified by maintaining the distinction between the two types of households that consist of a single head and households that consist of more than one adult. A further distinction is made by distinguishing between households based on the presence or absence of children and their respective ages.

Table 1 provides the definitions of the different life cycle stages, and the number of households that fall into each stage (indicated in brackets). The table is presented in a crossclassification format, making it possible to examine the implications of omitting the four cases in which there are children present in the households where the household head is 65 years of age or older. It also highlights the implications of combining the case where there are children present (youngest child younger than six) in a single-headed household where the head of the household is older than 35 and not retired.

\section{TABLE 1}

HOUSEHOLD LIFECYCLE STAGES AND SAMPLE DISTRIBUTION

\begin{tabular}{|c|c|c|c|}
\hline $\begin{array}{l}\text { Age of the } \\
\text { household } \\
\text { head }\end{array}$ & No Child & $\begin{array}{c}\text { Youngest child } \\
\text { less than } \\
6 \text { years old }\end{array}$ & $\begin{array}{c}\text { Youngest child } \\
6 \text { years } \\
\text { or older }\end{array}$ \\
\hline & \multicolumn{3}{|c|}{ Two or more adult household } \\
\hline $\begin{array}{l}\text { Head less than } \\
35 \text { years old }\end{array}$ & $\begin{array}{l}\text { Young couple } \\
(883)\end{array}$ & $\begin{array}{l}\text { Full nest I } \\
\qquad(2,365)\end{array}$ & $\begin{array}{l}\text { Full nest II } \\
\quad(756)\end{array}$ \\
\hline $\begin{array}{l}\text { Head } 35 \text { years and } \\
\text { older and not retired }\end{array}$ & $\begin{array}{c}\text { Childless couple } \\
(2,340)\end{array}$ & $\begin{array}{l}\text { Delayed full nest } \\
\qquad(4,770)\end{array}$ & $\begin{array}{l}\text { Full nest III } \\
\quad(5,805)\end{array}$ \\
\hline \multirow[t]{2}{*}{ Head retired } & $\begin{array}{l}\text { Older couple } \\
\quad(1,972)\end{array}$ & $\begin{array}{l}\text { Unassigned } 4 \\
(2,086)\end{array}$ & $\begin{array}{l}\text { Unassigned } 5 \\
\qquad(2,279)\end{array}$ \\
\hline & \multicolumn{3}{|c|}{ Single adult household } \\
\hline $\begin{array}{l}\text { Head less than } \\
35 \text { years old }\end{array}$ & $\begin{array}{l}\text { Bachelor I } \\
(1,072)\end{array}$ & $\begin{array}{l}\text { Single Parent I } \\
\text { (536) }\end{array}$ & $\begin{array}{c}\text { Single Parent II } \\
\text { (367) }\end{array}$ \\
\hline $\begin{array}{l}\text { Head } 35 \text { years and } \\
\text { older and not retired }\end{array}$ & $\begin{array}{l}\text { Bachelor II } \\
\quad(1,394)\end{array}$ & $\begin{array}{l}\text { Unassigned } 1 \\
\quad(537)\end{array}$ & $\begin{array}{c}\text { Single Parent III } \\
\text { (859) }\end{array}$ \\
\hline Head retired & $\begin{array}{l}\text { Bachelor III } \\
\quad(853)\end{array}$ & $\begin{array}{c}\text { Unassigned } 2 \\
\text { (179) }\end{array}$ & $\begin{array}{c}\text { Unassigned } 3 \\
(364)\end{array}$ \\
\hline
\end{tabular}

Table 1 reveals that 5623 households (19\% of the sample) fall into the four omitted cases, while the smallest of the included cases contains 367 households (Single parent II). The table also reveals that 179 households (about $0,60 \%$ of the sample) are not classified using the three household composition variables, and are likely to be "roommate" and "group" households.

Of particular interest, and arguably a phenomenon unique to the South African environment, is the overly inflated Unassigned 4 and 5 stages where the household head is retired and there are children present in the household. These stages represent 15 percent of the overall sample. 


\section{RESULTS AND DISCUSSION}

Measures of significance

Multivariate analysis of variance (MANOVA) was used to test for significant differences between the various stages of the HLC. The data set did not meet the requirements of equal withingroup variance/covariance matrices. One way to address this problem is to sample the larger groups and repeat the analysis with different samples and compare the statistics to ensure that sampling effects did not skew the results. It was found by Ito and Schull (in Morrison, 1976, p.141) that if the cell sizes are large and equal then violation of this requirement has little effect on the Type I error (the error of rejecting the null hypothesis when it is actually true) rate and the chosen significance level. In the current study there were 23 dependent variables and the minimum cell size was 180 .

MANOVA presents several criteria with which to assess multivariate differences across groups. According to Hair, Anderson, Tatham and Black (1995, p.277), the four most popular are Roy's greatest characteristic root, Wilks' lambda (also known as the $\mu$ statistic), Hotelling's trace, and Pillai's criterion.

Roy's greatest characteristic root measures the differences in only the first canonical root (or discriminant function) among the dependent variables. This criterion is advantageous in respect of the power and specificity of the test but makes it less useful in certain conditions where all dimensions should be considered. This test is most appropriate when the dependent variables are strongly interrelated in a single dimension, but it is also the measure most likely to be severely affected by violations of the assumptions mentioned earlier (Hair et al., 1995, p.277).

Unlike Roy's greatest characteristic root, Wilks' lambda considers all the characteristic roots - in other words it examines whether groups are somehow different without being concerned with whether they differ in at least one linear combination of the dependent variables. The larger the between-groups dispersion, the smaller the value of Wilks' lambda and the greater the implied significance (Hair et al., 1995, p.277). Rao (in loc. cit.) found that although the distribution of Wilks' lambda is complex, good approximations for significance testing are available by transforming it into an F statistic.
The two other measures that can be used include Pillai's criterion and Hotelling's trace. Both are similar to Wilks' lambda because they consider all the characteristic roots and can be approximated by an F statistic. The measure to use is the one most immune to violations of the assumptions underlying MANOVA. Hair et al. (1995, p.278) assert that Pillai's criterion and Wilks' lambda both meet these requirements, although Pillai's criterion is more robust and should be used if sample size decreases, unequal cell sizes appear, or homogeneity of covariances is violated. Wilks' lambda was used to assess significance in individual cell comparisons. The F statistic was considered significant at the $95 \%$ level of confidence.

\section{Hypothesis 1}

Hypothesis 1 is concerned with significant differences between the various stages of the HLC with reference to the households' overall consumption behaviour expressed as a percentage of their total income.

Table 2 shows overall household life cycle MANOVA test results.

TABLE 2

OVERALl hOUSEHOLd LIFECyCle MANOVA TEST RESUlts

\begin{tabular}{lccccc}
\hline Statistic & Value & F Value & Num DF & Den DF & Pr $>$ F \\
\hline Wilks' Lambda & 0,722548 & 23,47 & 414 & 420223 & $<0,0001$ \\
Pillai's Trace & 0,309631 & 22,5 & 414 & 532278 & $<0,0001$ \\
Hotelling-Lawley Trace & 0,341578 & 24,38 & 414 & 292602 & $<0,0001$ \\
Roy's Greatest Root & 0,143274 & 184,21 & 23 & 29571 & $<0,0001$ \\
\hline
\end{tabular}

MANOVA Test Criteria and F Approximations for the Hypothesis of No Overall Stage Effect

$H=$ Type III SSCP Matrix for Stage

$E=$ Error SSCP Matrix

$S=18 \quad M=2 \quad N=14776$

As can be seen in Table 2, MANOVA yielded a significant Wilks' lambda, Pillai's criterion and Hotelling's trace statistics, firmly implying an overall difference between the different life stages in the proposed life cycle model in terms of the dependent variables.

TABLE 3

INDIVIDUAL CELL COMPARISONS, SIGNIFICANCE OF THE F STATISTIC

\begin{tabular}{|c|c|c|c|c|c|c|c|c|c|c|c|c|c|c|c|c|c|}
\hline $\begin{array}{c}\text { Bachelor } \\
\text { I }\end{array}$ & $\begin{array}{c}\text { Bachelor } \\
\text { II }\end{array}$ & $\begin{array}{c}\text { Bachelor } \\
\text { III }\end{array}$ & $\begin{array}{c}\text { Childless } \\
\text { couple }\end{array}$ & $\begin{array}{l}\text { Delayed } \\
\text { nest }\end{array}$ & $\begin{array}{c}\text { Full nest } \\
\text { I }\end{array}$ & $\begin{array}{c}\text { Full nest } \\
\text { II }\end{array}$ & $\begin{array}{c}\text { Full nest } \\
\text { III }\end{array}$ & $\begin{array}{c}\text { Older } \\
\text { couple } \\
\text { I }\end{array}$ & $\begin{array}{c}\text { Single } \\
\text { parent } \\
\text { II }\end{array}$ & $\begin{array}{c}\text { Single } \\
\text { parent } \\
\text { III }\end{array}$ & $\begin{array}{l}\text { Single } \\
\text { parent }\end{array}$ & $\begin{array}{c}\text { Unassigned } \\
\text { I }\end{array}$ & $\begin{array}{l}\text { Unassigned } \\
\text { II }\end{array}$ & $\begin{array}{l}\text { Unassigned } \\
\text { III }\end{array}$ & $\begin{array}{l}\text { Unassigned } \\
\text { IV }\end{array}$ & $\begin{array}{c}\text { Unassigned } \\
\mathbf{V}\end{array}$ & $\begin{array}{c}\text { Unassigned } \\
\text { VI }\end{array}$ \\
\hline Bachelor II & $<.0001$ & & & & & & & & & & & & & & & & \\
\hline Bachelor III & $<.0001$ & $<.0001$ & & & & & & & & & & & & & & & \\
\hline $\begin{array}{l}\text { Childless } \\
\text { couple }\end{array}$ & $<.0001$ & $<.0001$ & $<.0001$ & & & & & & & & & & & & & & \\
\hline Delayed nest & $<.0001$ & $<.0001$ & $<.0001$ & $<.0001$ & & & & & & & & & & & & & \\
\hline Full nest I & $<.0001$ & $<.0001$ & $<.0001$ & $<.0001$ & $<.0001$ & & & & & & & & & & & & \\
\hline Full nest II & $<.0001$ & $<.0001$ & $<.0001$ & $<.0001$ & $<.0001$ & $=.0368$ & & & & & & & & & & & \\
\hline Full nest III & $<.0001$ & $<.0001$ & $<.0001$ & $<.0001$ & $<.0001$ & $<.0001$ & $<.0001$ & & & & & & & & & & \\
\hline Older couple & $<.0001$ & $<.0001$ & $<.0001$ & $<.0001$ & $<.0001$ & $<.0001$ & $<.0001$ & $<.0001$ & & & & & & & & & \\
\hline Single parent I & $<.0001$ & $<.0001$ & $<.0001$ & $<.0001$ & $<.0001$ & $<.0001$ & $<.0001$ & $<.0001$ & $<.0001$ & & & & & & & & \\
\hline $\begin{array}{l}\text { Single } \\
\text { parent II }\end{array}$ & $<.0001$ & $<.0001$ & $<.0001$ & $<.0001$ & $<.0001$ & $<.0001$ & $<.0001$ & $<.0001$ & $<.0001$ & $=.0838^{*}$ & & & & & & & \\
\hline $\begin{array}{l}\text { Single } \\
\text { parent III }\end{array}$ & $<.0001$ & $<.0001$ & $<.0001$ & $<.0001$ & $<.0001$ & $<.0001$ & $<.0001$ & $<.0001$ & $<.0001$ & $<.0001$ & $=.2634^{*}$ & & & & & & \\
\hline Unassigned (1) & $<.0001$ & $<.0001$ & $<.0001$ & $<.0001$ & $<.0001$ & $<.0001$ & $<.0001$ & $<.0001$ & $<.0001$ & $<.0001$ & $<.0001$ & $<.0001$ & & & & & \\
\hline Unassigned (2) & $<.0001$ & $<.0001$ & $<.0001$ & $<.0001$ & $<.0001$ & $<.0001$ & $<.0001$ & $<.0001$ & $<.0001$ & $=.0036$ & $<.0001$ & $<.0001$ & $=.1038^{*}$ & & & & \\
\hline Unassigned (3) & $<.0001$ & $<.0001$ & $<.0001$ & $<.0001$ & $<.0001$ & $<.0001$ & $<.0001$ & $<.0001$ & $<.0001$ & $<.0001$ & $<.0001$ & $<.0001$ & $<.0001$ & $=.0341$ & & & \\
\hline Unassigned (4) & $<.0001$ & $<.0001$ & $<.0001$ & $<.0001$ & $<.0001$ & $<.0001$ & $<.0001$ & $<.0001$ & $<.0001$ & $<.0001$ & $<.0001$ & $<.0001$ & $<.0001$ & $=.1002^{*}$ & $<.0001$ & & \\
\hline Unassigned (5) & $<.0001$ & $<.0001$ & $<.0001$ & $<.0001$ & $<.0001$ & $<.0001$ & $<.0001$ & $<.0001$ & $<.0001$ & $<.0001$ & $<.0001$ & $<.0001$ & $<.0001$ & $=.0019$ & $<.0001$ & $<.0001$ & \\
\hline Unassigned (6) & $<.0001$ & $<.0001$ & $<.0001$ & $<.0001$ & $<.0001$ & $<.0001$ & $<.0001$ & $<.0001$ & $<.0001$ & $=.0017$ & $=.0095$ & $<.0001$ & $<.0001$ & $=.0032$ & $<.0001$ & $<.0001$ & $<.0001$ \\
\hline Young couple & $<.0001$ & $<.0001$ & $<.0001$ & $<.0001$ & $<.0001$ & $<.0001$ & $<.0001$ & $<.0001$ & $<.0001$ & $<.0001$ & $<.0001$ & $<.0001$ & $<.0001$ & $<.0001$ & $<.0001$ & $<.0001$ & $<.0001$ \\
\hline
\end{tabular}

* Comparison not significantly different at the $95 \%$ level of confidence. 
Although this indicates overall significant difference, it does not show which stages differ from each other and how many of them differ. It may be that just a single stage differs from the rest, resulting in an overall significant difference between all the stages.

It was therefore necessary to carry out a multiple comparison of means, separately comparing the mean of each stage with that of every other stage. The levels of significance of the F statistic are given in Table 3.

It was found that virtually all the life stages were significantly different from one another with regard to their overall consumption behaviour.

From a possible 171 comparisons only four stages $(2,34 \%)$ proved not to be significantly different at the $95 \%$ level of confidence. The majority of the stages $(93,57 \%)$ were found to be significantly different at the $99 \%(\mathrm{p}<0,0001)$ level of confidence. A brief discussion follows on each of the stages that were not significantly different with regard to their overall consumption behaviour. To simplify the discussion, it was decided to report only on the stages that showed F statistics at less than the 95\% level of confidence and those dependent variables that signalled differences smaller than the $95 \%$ level of confidence.

The Single parent stages displayed a high degree of similarity through the HLC stages $(\mathrm{p}=0,0838)$. The results are shown in Table 4 .

TABLE 4

Differences between Single Parent I ANd Single Parent II HOUSEHOLDS

\begin{tabular}{lcc}
\hline Dependent variable & Single parent I & Single parent II \\
\hline Bond Repayments & $1,336 \%$ & $2,571 \%$ \\
Education & $1,150 \%$ & $1,753 \%$ \\
Holiday accommodation & $1,060 \%$ & $1,350 \%$ \\
Rental, board, and lodging & $2,241 \%$ & $3,305 \%$ \\
\hline
\end{tabular}

As can be seen from Table 4 the only dependent variables that were significantly different between the Single parent I and Single parent II stages were bond repayments, education, holiday accommodation and rental board and lodging.

The reason for this is that these stages had only a single parent (not two income earners) who had to cover the increased cost of living with a single salary. The higher mean expenditure on education for the second stage could be attributable to the fact that all the children in the household had reached school age.

A high degree of similarity between the Single parent II and III stages $(p=0,2634)$ was found, implying that simply having a household head who had reached 35 did not significantly change household consumption behaviour.

The differences between Single parent II and Single parent III households were found to be in the consumption of household services where the Single parent III stage showed a higher mean than the Single parent II stage. This could be attributed to the higher mean age of all the people in the household, resulting in increased consumption of such services. Household services include contributions made toward levy, rates and taxes, water and electricity, sanitary services, right to access tribal land, communal housing services, domestic worker cash wages, household fuel and communication an other household services.

The Unassigned I and II stages also revealed a high degree of similarity $(p=0,1038)$. Both were single parent type households with children under school age. The only difference between the two in terms of their composition was that the adult in the latter stage had reached retirement age.
The only dependent variables - indicating significant differences in consumption - were food, beverage and household consumption goods, and functional public transportation. Functional public transportation obviously decreases after retirement due to the change in employment status and the reduced need to commute between work and home. Interestingly, the mean expenditure on food, beverage and household consumption goods was higher in the Unassigned II stage.

Finally, the Unassigned II and III stages showed a high degree of similarity $(\mathrm{p}=0,1002)$. These household formats consist of single parents with children in the household. Table 5 shows the results.

TABLE 5

IFFERENCES BETWEen SINGLE PARENT II AND SINGLE PARENT III HOUSEHOLDS

\begin{tabular}{lcc}
\hline Dependent variable & Unassigned II & Unassigned III \\
\hline Home repairs and improvements & $0,898 \%$ & $0,123 \%$ \\
Household services & $11,256 \%$ & $14,174 \%$ \\
\hline
\end{tabular}

Table 5 illustrates that the only dependent variables where these groups were significantly different were home repairs and household services. In essence the only difference between these two household formats is the age of the youngest child in the household. The difference in expenditure could be attributed to the higher mean age of the children in the household, resulting in increased consumption of household services and possibly an increased need for physical space.

Hypothesis 1 is accepted because at the time of the survey the HLC model effectively distinguished between 97,66 percent of South African households with regard to their consumption behaviour at the $95 \%$ level of confidence. The basic logic underlying the HLC theory is therefore also accepted as valid.

\section{Hypothesis 2}

Hypothesis 2 is concerned with the differences in consumption behaviour within the various stages of the HLC with reference to population group.

To avoid the problem of unbalanced cell sizes it was decided to take one life stage from each of the various life paths that yielded the highest overall balance in the sample sizes. Accordingly, in testing whether there were any significant differences in consumption behaviour within the stages with regard to the population group of the head of the household the following stages were selected: (1) Bachelor III, (2) Childless couple, (3) Full nest III, (4) Single parent III, and (5) the Unassigned $\mathrm{V}$ stages. The sample was stratified according to four population classes: (1) African/Black, (2) Coloured, (3) Indian/Asian, and (4) White. Table 6 shows the results of the MANOVA test.

TABLE 6

MANOVA RESULTS - DIFFERENCES BETWEEN POPULATION GROUPS

\begin{tabular}{lccccc}
\hline Statistic & Value & F Value & Num DF & Den DF & Pr > F \\
\hline Wilks' Lambda & 0,53778602 & 295,43 & 69 & 88337 & $<.0001$ \\
Pillai's Trace & 0,48162137 & 245,88 & 69 & 88713 & $<.0001$ \\
Hotelling-Lawley Trace & 0,82360729 & 352,93 & 69 & 77745 & $<.0001$ \\
Roy's Greatest Root & 0,77815703 & 1000,47 & 23 & 29571 & $<.0001$ \\
\hline
\end{tabular}

MANOVA Test Criteria and F Approximations for the Hypothesis of No Overall Population Effect

$H=$ Type III SSCP Matrix for Population

$E=$ Error SSCP Matrix

$S=3 \quad M=9,5 \quad N=14783,5$ 
From Table 6 it is evident that at the time of the testing there were significant differences between the various population groups with regard to their overall consumption behaviour within the various cells of the HLC. Consequently Hypothesis 2 is accepted.

\section{Hypothesis 3}

Hypothesis 3 is concerned with the differences in consumption behaviour within the various stages of the HLC with reference to the level of income in the household.

Table 7 shows the MANOVA results on the differences in consumption behaviour between levels of income.

TABLE 7

MANOVA RESULTS - DIFFERENCES BETWEEN LEVELS OF INCOME

\begin{tabular}{lccccc}
\hline Statistic & Value & F Value & Num DF & Den DF & Pr $>$ F \\
\hline Wilks' Lambda & 0,44777768 & 286,31 & 92 & 117036 & $<.0001$ \\
Pillai's Trace & 0,59532288 & 224,81 & 92 & 118284 & $<.0001$ \\
Hotelling-Lawley Trace & 1,13779946 & 365,66 & 92 & 99247 & $<.0001$ \\
Roy's Greatest Root & 1,04823176 & 1347,71 & 23 & 29571 & $<.0001$
\end{tabular}

MANOVA Test Criteria and F Approximations for the Hypothesis of No Overall income class Effect

$H=$ Type III SSCP Matrix for income class

$E=$ Error SSCP Matrix

$S=4 \quad M=9 \quad N=14783$

As can be seen in Table 7, there were significant differences between the mean consumption behaviour of households within the different stages of the HLC with regard to the level of income in the household. Hypothesis 3 is therefore accepted because at the time of the testing there were significant differences in the mean consumption behaviour of households within each of the stages of the HLC based on the income level in the household.

\section{Hypothesis 4}

Hypothesis 4 is concerned with the significant differences between the mean consumption behaviour of households within the various stages of the HLC with reference to their level of urbanisation.

As with Hypotheses 2 and 3, it was necessary to select cells that had balanced sizes. The following life stages were selected: (1) Bachelor II, (2) Childless couple, (3) Full nest III, (4) Single parent III, and (4) the Unassigned V stages. Table 8 shows the results of the MANOVA test on differences in consumption behaviour between levels of urbanisation.

TABLE 8

MANOVA RESULTS - DIFFERENCES BETWEEN LEVELS OF URBANISATION

\begin{tabular}{lccccc}
\hline Statistic & Value & F Value & Num DF & Den DF & Pr $>$ F \\
\hline Wilks' Lambda & 0,76101336 & 396,67 & 23 & 29052 & $<0,0001$ \\
Pillai's Trace & 0,23898664 & 396,67 & 23 & 29052 & $<0,0001$ \\
Hotelling-Lawley Trace & 0,31403738 & 396,67 & 23 & 29052 & $<0,0001$ \\
Roy's Greatest Root & 0,31403738 & 396,67 & 23 & 29052 & $<0,0001$ \\
\hline
\end{tabular}

MANOVA Test Criteria and Exact F Statistics for the Hypothesis of No Overall Urban Level Effect

$H=$ Type III SSCP Matrix for Urban Level

$E=$ Error SSCP Matrix

$S=1 \quad M=10,5 \quad N=14525$
From the results presented in Table 8 , Hypothesis 4 can be accepted because of the significant differences in the mean consumption behaviour between households within the HLC with regard to their level of urbanisation.

\section{CONCLUSIONS AND RECOMMENDATIONS}

The findings indicate that the Gilly and Enis (1982) HLC model accommodates/covers about 80 percent of households in South Africa, implying that the model is not totally appropriate in dealing with non-traditional household formats in South Africa. To overcome this problem a modified version of the Gilly and Enis (1982) HLC model was used to verify the model's usefulness in determining market segmentation.

It emerged that households between the various stages of the HLC differed significantly with regard to their overall consumption behaviour.

The only stages of the HLC that did not show significant differences in consumption behaviour were the Single parent stages, the Unassigned I and II stages, as well as the Unassigned II and III stages.

The consumption variables that did show significant differences between the Single parent I and Single parent II stages were those directly linked to the ages of the children in the household. Since the only difference between the Single parent I and Single parent II stages is the age of the youngest child in the household, the value of using the children's age in the household as a life stage delineator is confirmed.

The Single parent II and Single parent III stages differed with regard to the amount of household services they consumed: it was therefore concluded that simply having the head of the household reach the age of 35 , is a poor household life stage delineator.

The Unassigned I and II stages differed only in terms of the amount they spent on food, beverage and general consumption goods, as well as on functional public transportation. Since the only difference between these two household formats is that the head of the household is retired in one of them, it is argued that the Unassigned II stage will spend less on functional public transportation as such transportation is usually used to get to work and back. In terms of the difference in the amount spent on food, this could be attributable to the reduced discretionary income associated with retirement.

With the Unassigned II and III stages, the only composition differences are the ages of the children in the household. Here the only significant consumption pattern differences between the household formats were the increased consumption of household services (e.g. electricity) and home repairs and improvements (the first stage revealed higher mean consumption). It could be argued that the increased consumption of household services is a consequence of the increased age of the children in the household. As far as home improvements and repairs are concerned, it is highly unlikely that retired women (older than 64 years) would have children at that age. It is consequently assumed that it is the children of family members that move in with them - therefore the increased need for physical living space.

Finally, while the HLC model provides a good explanation of the differentiation between households, significant levels of variance were found within each of the stages. When the differences in consumption behaviour between households with reference to population group, level of urbanisation and level of household income were compared, significant differences between these groupings emerged. 
Three main conclusions can be drawn from this study: First, it is likely that modernised HLC models will continue to evolve to keep track of changing norms and values in society, as well as the sociodemographic peculiarities encountered in specific countries.

Second, the only classification variable that distinguishes Single parent households from one another is the attainment of the age of 35 by the household head. The differences in consumption behaviour are not significant. It is therefore concluded that using the attainment of the age of 35 in isolation, is problematic in differentiating between Single parent households and that other variables should be considered to differentiate between these households.

Third, while overall household consumption behaviour differed between the stages of the HLC, there were significant levels of within-stage heterogeneity. This was confirmed by comparing the consumption behaviour of households between population groups, levels of urbanisation and levels of household income. One way of addressing this problem might be to expand the number of HLC composition variables, for example by including variables such as population group. This would not only lead to a decrease in the within-stage heterogeneity, but also to an increase in the number of HLC models beyond practical levels.

Although it has proven helpful in differentiating between households' consumption behaviour, the exclusive use of the HLC model in segmenting markets could prove problematic due to the high level of within-stage heterogeneity.

Ideally, organisations should employ more than one segmentation technique to gain an in-depth understanding of their respective target market(s). The HLC approach to segmentation obviously will not prove useful in all situations, but it does provide valuable insight into the types of pressures households face and how they are likely to react to them.

Although contemporary marketing literature gives some insight into the types of household-related pressures that influence household consumption behaviour, it does not cover all the variables that influence such behaviour.

\section{Limitations of the study}

The Unassigned IV and V household stages constituted about 15 percent of the overall sample. This is significant by international standards, given the results of a similar study conducted in Canada where these stages constituted less than 0,2 percent (Liu $\&$ Putler, 2001, p.13). These households are characterised by retired household heads and the presence of children (aged younger than six and older than six respectively). These stages have been found to apply predominantly to black South Africans as well as middle to lower income classes.

They have also proven to be significantly different in terms of their overall consumption behaviour compared to all the other stages in the HLC. Purely from observation, these two household formats do not seem to be a very profitable segment to target, when compared to Childless couple and Bachelor-type households, but they do signal an interesting trend in household composition. Although these households consisted predominantly of black South Africans at the time of the survey, it is surmised that other population groups may start showing similar trends.

A further limitation of the study was that the educational qualifications of the head of the household could not be ascertained, and there is reason to believe that this could well influence household consumption behaviour.

Although the results of the survey are based on 1995 information, this should not detract from the objectives of the research.

\section{Future research}

That different pressures influence consumption behaviour through the HLC cannot be disputed. However because the HLC model does not cover all the variables that influence the consumer decision-making process, this approach to segmentation is limited in its usefulness when compared to more sophisticated segmentation techniques such as cluster analysis.

Future research could focus on comparing the values, attitudes and perceptions through the various HLC stages. This could prove invaluable in value-proposition construction. Such research could be supplemented with the latest data from the household income and expenditure survey.

This study found that the HLC adequately isolates households with regard to their consumption behaviour expressed as a percentage of their total income. Although the results presented in the study may be of limited use in the actual application of the HLC model as a segmentation technique, the underlying logic supporting the model has been confirmed.

The reason marketers find the logic of the HLC model so appealing may be because they can relate to it on such a personal level. The model covers a number of life-changing events traced through the life span of the household. These events exert pressures on the needs of households and consequently result in different consumption patterns.

The life-changing events accommodated in the HLC model by no means cover all such events that can be experienced by a particular target segment, nor does the model cover all the factors that can affect consumption behaviour. Marketers should identify those life-changing events that are relevant to the context they are presenting their offerings in and study the effects of such events.

\section{REFERENCES}

Arnould, E.J., Price, L. \& Zinkhan, G. (2002). Consumers. New York: McGraw-Hill.

Derrick, F.W. \& Lehfeld, A.K. (1980). The family life cycle: an alternative approach. Journal of Consumer Research, 7 (September), 214-217.

Gilly, M.C. \& Enis, B.M. (1982). Recycling the family life cycle: a proposal for redefinition. Advances in Consumer Research, Mitchell, A.M. (ed.), Vol. 9, Association for Consumer Research, Michigan: Ann Arbor.

Hawkins, D.I., Best, R.J. \& Coney, K. A.. (2001). Consumer Behavior. Boston, USA: Irwin McGraw-Hill.

Hair J.F., Anderson R.E., Tatham R.T. \& Black W.C. (1995) Multivariate Data Analysis (4th ed.). New Jersey: PrenticeHall.

Hirschowitz, R. (1997). Earning and spending in South Africa: Selected findings of the 1995 income and expenditure survey. Statistics South Africa, Pretoria.

Kotler, P. (2000). Marketing Management (The Millennium Edition). New York: Prentice-Hall.

Langschmidt, T. \& Hoets, P. (2001). Futurefact: Trendscape 2001. Industry Report, Johannesburg.

Liu, Y. \& Putler, D.S. (2001). Household Life-Cycle Theory: An Empirical Examination of Received Wisdom. Working Paper. Vancouver: University of British Columbia.

Morrison, D.F. (1976). Multivariate Statistical Methods (2nd ed.) New York: McGraw-Hill.

Murphy, P.E. \& Staples, W.A. (1979). A modernized family life cycle. Journal of Consumer Research, 6, 12-22.

Neal, C.M., Quester, P.G. \& Hawkins, D. I. (2002). Consumer Behaviour. $3^{\text {rd }}$ Edition. Roseville, Australia: McGraw-Hill. 
Redondo-Bellón, I., Royo-Vela, M. \& Alidás-Manzano, J. (2001). A family lifecycle model adapted to the Spanish environment. European Journal of Marketing, 35 (5/6), 612638.

Schaninger, C.M. \& Danko, W.D. (1993). A conceptual and empirical comparison of alternative household life cycle models. Journal of Consumer Research, 19, 580-594.

Schiffman, L.G. \& Kanuk, L.L. (1997). Consumer Behavior (6 $6^{\text {th }}$ ed.). New Jersey: Simon and Schuster Company.

Statistics South Africa, (1995). Income and Expenditure Survey: Questionnaire. Pretoria: Statistics South Africa.

Wells, W.D. \& Gubar, G. (1966). Life cycle concept in marketing research. Journal of Marketing Research, 3, 355-363.

Wilkes, R.E. (1995). Household Life-Cycle Stages, Transitions, and Product Expenditures. Journal of Consumer Research, 22 (1), 27-42. 